\title{
A Comparison of Purine Derivatives Excretion with Conventional Methods as Indices of Microbial Yield in Dairy Cows
}

\author{
M. González-Ronquillo, ${ }^{1}$ J. Balcells, ${ }^{2}$ A. Belenguer, ${ }^{2}$ C. Castrillo, ${ }^{2}$ and M. Mota ${ }^{2}$ \\ ${ }^{1}$ Departamento de Producción Animal, Facultad de Medicina Veterinaria y Zootecnia. \\ Universidad Autónoma del Estado de México, 50000 Toluca, Mexico \\ ${ }^{2}$ Departamento de Producción Animal y Ciencia de los Alimentos, Universidad de Zaragoza, \\ C/Miguel Servet 177, 50013 Zaragoza, Spain
}

\begin{abstract}
Three multiparous, ruminally and duodenally cannulated Holstein-Friesian milking cows $(558 \pm 14 \mathrm{~kg}$ BW) with a mean milk yield of $19.9 \pm 1.4 \mathrm{~kg} / \mathrm{d}$ in their 4th mo of lactation were fed a mixed diet of forage and concentrate at 100,85 , and $75 \%$ of ad libitum intake in a $3 \times 3$ Latin square design. Duodenal digesta flow was estimated using the dual-phase technique in which Cr-EDTA and Yb-acetate were used as liquid and solid markers, respectively. Microbial N (MN) was estimated using the duodenal flow of purine bases (PB); bacterial isolates from the rumen liquid and solid phases were used as references. Additionally, duodenal flow of $\mathrm{PB}$ and $\mathrm{MN}$ were estimated indirectly using the excretion of purine derivatives (PD) in urine and milk. Duodenal flow of PB and derived MN tended to decrease with feed restriction (from 258 to $154 \mathrm{mmol} /$ $\mathrm{d}$ and 123.5 to $74.4 \mathrm{~g} / \mathrm{d}$, respectively). Estimates of $\mathrm{PB}$ and MN based on urinary PD showed the same trend, and decreases in PB (from 314 to $266 \mathrm{mmol} / \mathrm{d}$, using LAB) were statistically significant. Using LAB, efficiencies of microbial protein synthesis in the ad libitum treatment were 12.9 and $17.0 \mathrm{~g}$ of $\mathrm{MN} / \mathrm{g}$ of organic matter apparently digested in the rumen when estimated using duodenal PB and urinary excretion of PD, respectively. Urinary excretion of PD closely reflected changes in duodenal flow of $\mathrm{PB}$ as a result of feed restriction.
\end{abstract}

(Key words: microbial synthesis, purine derivative, milk, dairy cow)

Abbreviation key: $\mathbf{C T}=$ creatinine excretion, $\mathbf{D O M}=$ digestible OM, LAB = liquid-associated bacteria, $\mathbf{L A P}=$ liquid-associated protozoa, $\mathbf{M N}=$ microbial $\mathbf{N}$, NA = nucleic acid, OMADR = OM apparently digested in the rumen, $\mathbf{P B}=$ purine base, $\mathbf{P D}=$ purine derivative, $\mathbf{S A B}=$ solid-associated bacteria.

Received September 10, 2003.

Accepted March 2, 2004.

Corresponding author: J. Balcells; e-mail: balcells@posta. unizar.es.

\section{INTRODUCTION}

In all of the new systems used to estimate the supply of duodenal protein, rumen yield of microbial protein has the largest element of uncertainty (NRC, 2001). Typically, measurements of microbial yield are based on the evaluation of a microbial marker in a limited number of rumen or duodenum-cannulated animals. That method is time-consuming and produces a high standard error of the estimate and should be used with caution.

Nucleic acids (NA) and their constituent purine bases (PB) are commonly used as microbial markers (ARC, 1984). Purine bases are efficiently absorbed and partially metabolized to purine derivatives (PD) (i.e., allantoin and uric acid) and are excreted, primarily, in urine but also through other fluids, such as milk.

The relationship between duodenal input and urinary output of purines has been studied extensively (Balcells et al., 1991; Vagnoni et al., 1997). To provide a simpler, non-invasive alternative to conventional methods of estimating microbial protein flow to the duodenum, several response models have been developed in a variety of species, including sheep (Chen et al., 1990; Balcells et al., 1991), cattle (Verbic et al., 1990; Orellana-Boero et al., 2001), milking cows (González-Ronquillo et al., 2003), goats (Belenguer et al., 2002), and buffalo (Pimpa et al., 2003). Additionally, the relationship between duodenal input of $\mathrm{PB}$ and PD output through milk has been described in dairy animals (Giesecke et al., 1994; González-Ronquillo et al., 2003), and milk PD output, which is easier to sample and measure than urine PD, has been proposed as an index of rumen microbial protein yield.

The aim of this study was to examine the validity of PD excretion, either through urine or milk, as a predictive index of rumen microbial yield when compared with direct measurements using duodenally cannulated animals and $\mathrm{PB}$ as microbial markers. To create a range in microbial $\mathbf{N}$ (MN) synthesis in the rumen, the amount of $\mathrm{OM}$ intake was manipulated in a Latin square experimental design. 
Table 1. Ingredient and chemical composition of the concentrate, roughage, and the overall ration fed to 3 lactating dairy cows, each subjected to 100,85 , and $75 \%$ ad libitum diets in a Latin square experimental design.

\begin{tabular}{|c|c|c|c|c|c|}
\hline & \multicolumn{4}{|c|}{ Concentrate } & Roughage \\
\hline \multicolumn{6}{|l|}{ Ingredient (g/kg of DM) } \\
\hline Corn grain & & 160.0 & & & \\
\hline Barley grain & & 54.0 & & & \\
\hline Soybean meal & & 134.0 & & & \\
\hline Wheat bran & & 170.0 & & & \\
\hline $\begin{array}{l}\text { Vitamin and mineral } \\
\text { supplement }{ }^{1,2}\end{array}$ & & & & & 250.0 \\
\hline Vetch-oat hay & & & & & 250.0 \\
\hline Alfalfa hay & & & & & 176.8 \\
\hline Sugar beet pulp (SBP) & & & & & 55.0 \\
\hline Chemical composition & Concentrate & $\begin{array}{l}\text { Alfalfa } \\
\text { hay }\end{array}$ & $\begin{array}{l}\text { Vetch-oak } \\
\text { hay }\end{array}$ & SBP & $\begin{array}{l}\text { Overall } \\
\text { ration }\end{array}$ \\
\hline $\mathrm{DM}$ (g/kg fresh matter) & 870 & 910 & 860 & 900 & 881 \\
\hline $\mathrm{OM}(\mathrm{g} / \mathrm{kg}$ of $\mathrm{DM})$ & 921 & 873 & 848 & 892 & 895 \\
\hline $\mathrm{CP}(\mathrm{g} / \mathrm{kg}$ of $\mathrm{DM})$ & 168 & 160 & 117 & 80 & 152 \\
\hline NDF (g/kg of DM) & 222 & 358 & 443 & 432 & 306 \\
\hline $\mathrm{ADF}(\mathrm{g} / \mathrm{kg}$ of $\mathrm{DM})$ & 60 & 279 & 216 & 231 & 152 \\
\hline $\mathrm{NE}_{\mathrm{L}}{ }^{3}(\mathrm{Mcal} / \mathrm{kg}$ of $\mathrm{DM})$ & 0.965 & 0.210 & 0.595 & 0.081 & 1.85 \\
\hline
\end{tabular}

${ }^{1}$ Provided $28.75 \mathrm{~g}$ of $\mathrm{Zn}, 15 \mathrm{~g}$ of $\mathrm{Mg}, 28.5 \mathrm{~g}$ of $\mathrm{Mn}, 10 \mathrm{~g}$ of $\mathrm{Fe}, 3.5 \mathrm{~g}$ of $\mathrm{Cu}, 0.125 \mathrm{~g} \mathrm{Co}, 0.055$ of $\mathrm{I}$, and 37.5 $\mathrm{g} / \mathrm{kg}$ of DM.

${ }^{2}$ Provided 3,500,000 IU of vitamin A, $625,000 \mathrm{IU}$ of vitamin $\mathrm{D}_{3}, 3.75 \mathrm{~g}$ of vitamin $\mathrm{E}$, and $5 \mathrm{~g}$ of nicotinic acid/kg of DM (NUTRAL, SA, Spain).

${ }^{3}$ Estimated from NRC (2001) tables.

\section{MATERIALS AND METHODS}

\section{Animals and Diets}

Three multiparous crossbred Holstein-Friesian cows $(558 \pm 14 \mathrm{~kg}$ of BW) in the 4th mo of lactation (mean milk yield $=19.9 \pm 1.4 \mathrm{~kg} / \mathrm{d}$ ) were fitted with a simple cannula (internal $\varnothing=6.5 \mathrm{~cm}$ ) in the rumen and a T-shaped cannula in the proximal duodenum, $5 \mathrm{~cm}$ distal to the pylorus. Animals were housed in a tiestall barn and fed a mixed diet (48:52 forage:concentrate ratio) at each of 3 levels $(100,85$, and $75 \%$ of ad libitum intake) in a $3 \times 3(30-d$ periods $)$ Latin square design.

Ingredients and chemical composition of the diets are provided in Table 1. Daily rations were distributed in 12 equal meals (concentrate plus forage) using automatic feeders. Dry matter intake was recorded from parturition, and ad libitum was considered as the average level of intake during wk 14 to 16 before parturition, with $<5 \%$ of daily refusals. Cows were weighed before and after each experimental period and milked twice a day at 0800 and $1700 \mathrm{~h}$.

\section{Experimental Procedures}

The experiment was performed when cows were between wk 16 and 32 of lactation. Each period lasted for $30 \mathrm{~d}$ and included $15 \mathrm{~d}$ for transition between diet regimes and $15 \mathrm{~d}$ for measurements. The sampling protocol included 1) a continuous infusion of flow markers from d 15 to 30,2 ) a digestibility trial from d 17 to 24,3 ) urine sampling from d 24 to 27,4 ) collection of duodenal digesta on d 27 and 28, and 5) sampling of rumen digesta for the isolation of rumen bacteria (d 29) and characterization of rumen fermentation.

\section{Marker Dosing and Rumen and Duodenal Sampling}

The duodenal flow of $\mathrm{PB}$ was determined using the dual-marker system (Faichney, 1975) with Cr-EDTA $(3.12 \mathrm{~g} / \mathrm{d})$ and $\mathrm{YbCl}(1.12 \mathrm{~g} / \mathrm{d})$ as the liquid and solidphase markers, respectively, infused continuously and independently into the rumen. During the 48 -h duodenal collection period, the cannula was opened every 6 $\mathrm{h}$ and 150 - to $200-\mathrm{mL}$ samples of chymus were collected in a jar and pooled for each cow. Samples of whole and solid digesta fractions were obtained by centrifugation (1000 g and $5 \mathrm{~m}$; Faichney, 1975) and freeze-dried for later analysis.

To trap particulate matter, $1 \mathrm{~L}$ of rumen content from each cow was squeezed through 4 layers of cheesecloth and filtered through a 50- $\mu \mathrm{m}$ nylon filter. The liquid fraction was used to extract bacteria (liquidassociated bacteria, LAB) by differential centrifugation (Martín-Orúe et al., 1998). Liquid-associated protozoa (LAP) were isolated by centrifugation (500 g and 
$5 \mathrm{~m}$; Martín-Orúe et al., 2000b) from the liquid fraction before passing through the nylon filter. After incubation in Coleman solution (Coleman, 1978) at $39^{\circ} \mathrm{C}$ for $60 \mathrm{~min}$, for the extraction of solid-associated bacteria (SAB), rumen particulate were washed twice with a total of $1 \mathrm{~L}$ of McDougal buffer, and the effluent was subjected to differential centrifugation (Martín-Orúe et al., 1998). All microbial isolates were freeze-dried and retained for analysis.

Using a manual vacuum pump, rumen fluid from the dorsal sac was sampled at $0,2,4,6,8,12,24$, and $36 \mathrm{~h}$ after feeding, and, immediately, the $\mathrm{pH}$ of the samples was recorded. To remove coarse particles, the fluid was filtered through 4 layers of surgical gauze. From the filtered rumen fluid, 2 samples were drawn and acidified. To determine $\mathrm{N}-\mathrm{NH}_{3}$ content, one sample was acidified with $\mathrm{HCl}(25 \mathrm{~mL} 0.2 \mathrm{M} \mathrm{HCl})$ (Chaney and Marbach, 1962). To determine volatile fatty acid content, the second sample was acidified with $\mathrm{H}_{3} \mathrm{PO}_{4}$ (1 mL of $0.5 \mathrm{M} \mathrm{H}_{3} \mathrm{PO}_{4}, 50 \mathrm{mM}$ 4-methyl-valerate per $4 \mathrm{~mL}$ of rumen fluid). Samples were stored at $-20^{\circ} \mathrm{C}$ until analysis.

\section{Whole Tract DM Apparent Digestibility}

Whole tract DM apparent digestibility coefficients were determined for each cow, based on 7 consecutive $\mathrm{d}$ of refusals and total faecal collections. On each sampling day, feces were weighed and thoroughly mixed. Representative subsamples (5\% fresh matter basis) were collected and stored at $-20^{\circ} \mathrm{C}$ for subsequent analysis.

\section{Urine and Milk Collection}

Urine was collected daily into sulphuric acid (to maintain $\mathrm{pH}<3$ ) using an external separator stuck to the vulva (Martín-Orúe et al., 2000a). After that, 2 samples ( $2 \%$ of the total volume) were drawn, pooled, and stored at $-20^{\circ} \mathrm{C}$.

To account for possible losses during urine collection, inulin (from Dahlia Tuber 9005 to 80 to 5; Sigma Co., St. Louis, MO) was used as a urinary marker. Inulin was diluted in a saline solution $(0.15 \mathrm{M} \mathrm{NaCl})$ to $17.4 \mathrm{~g} / \mathrm{L}$ at $60^{\circ} \mathrm{C}$, filtered $(0.45 \mu \mathrm{m}$; Millipore, Bedford, MA), sterilized $\left(30 \mathrm{~min}\right.$ at $\left.100^{\circ} \mathrm{C}\right)$, and infused for 36 $\mathrm{h}$ via a temporary jugular catheter with a flow rate of $0.4 \mathrm{~mL} / \mathrm{min}$. The rate of creatinine excretion (CT, $\mathrm{mg}$ / min) was estimated from the infusion rate of inulin $(\mathrm{mg} / \mathrm{min})$ and used to calculate the daily excretion of urinary compounds (Martín-Orúe et al., 2000a). The inulin trial was performed at the end of the experiment (33th wk of lactation).
Milk yield was recorded daily, and two 100-mL samples were drawn from the collection jar just after milking at 0800 and $1700 \mathrm{~h}$. Samples were stored at $-20^{\circ} \mathrm{C}$ until analysis.

\section{Analytical Procedures}

Feed ingredients were analyzed for DM and OM following AOAC (1980). Neutral detergent fiber, ADF, and acid detergent lignin concentrations in the feeds were determined using the procedures of Goering and Van Soest (1970). Total N and NAN content in duodenal digesta were determined using the Kjeldahl method, with Se as the catalyst. Ammonia from NAN samples was first evaporated by drying samples at $\mathrm{pH}$ $>10$ (Firkins et al., 1992). Volatile fatty acids were analyzed using gas liquid chromatography (Jouany, 1982).

Flow-marker $(\mathrm{Cr}-\mathrm{Yb})$ concentrations in digesta and infusates were determined by atomic absorption spectrophotometry using a nitrous oxide acetylene flame (Siddons et al., 1985). The PD (allantoin and uric acid) and creatinine in urine and milk were analyzed using HPLC (Balcells et al., 1992b; Martín-Orúe et al., 1996). The PB in the rumen and duodenal digesta contents were determined after hydrolysis of the samples by HPLC (Martín-Orúe et al., 1996). Inulin in urine and infusates was analyzed colorimetrically (Jung et al., 1990).

\section{Calculations and Statistical Analysis}

Duodenal flow of PB was calculated by reference to Cr-EDTA and Yb-acetate as fluid and solid markers, respectively (Faichney, 1975). Microbial N was determined directly in the duodenum using $\mathrm{PB}$ as a microbial marker and, indirectly, using urinary or milk excretion of PD following the response models proposed by González-Ronquillo et al. (2003). For urine, y = $58.86+0.70 \mathrm{x}$, where $\mathrm{y}$ is the $\mathrm{PD}$ excreted in urine (allantoin plus uric acid, $\mathrm{mmol} / \mathrm{d}$ ) and $\mathrm{x}$ is the duodenal flow of PB (adenine plus guanine, $\mathrm{mmol} / \mathrm{d}$ ). For milk, $\mathrm{y}=-5.14+0.376 \mathrm{x}_{1}+0.011 \mathrm{x}_{2}$, where $\mathrm{y}$ is the PD excreted through the milk (allantoin plus uric acid, $\mathrm{mmol} / \mathrm{d}), \mathrm{x}_{1}$ is milk yield (kg/d), and $\mathrm{x}_{2}$ is the duodenal flow of PB (adenine plus guanine, $\mathrm{mmol} / \mathrm{d}$ ).

Assuming that most duodenal PB come from digested microbes, the microbial duodenal flow was calculated using $\mathrm{PB}: \mathrm{N}$ of reconstituted digesta and rumen bacterial isolates $\left[\mathrm{MN}=(\mathrm{PB}: \mathrm{NAN})_{\text {chymus }} /(\mathrm{PB}: \mathrm{N})_{\text {bacteria }}\right]$.

Creatinine excretion rate $(\mathrm{mg} / \mathrm{min})$ was calculated by inulin infusion $(\mathrm{mg} / \mathrm{min})$ and urinary inulin:creatinine [i:ct] ratio $\left(\mathrm{CT}=\mathrm{I} / \mathrm{i}: c \mathrm{t}_{\mathrm{A}}\right)$; once inulin reached 
the equilibrium within the liquid body pools, that was determined as the mono-exponential function:

$$
\mathrm{Y}=\mathrm{A}\left(1-\mathrm{e}^{-\mathrm{kt}}\right)
$$

where $\mathrm{Y}$ is the $\mathrm{i}$ :ct value, $\mathrm{t}$ is the time after infusion, and $\mathrm{A}$ is the asymptotic value of $\mathrm{i}$ :ct to be reached at the equilibrium time $t_{(A)}$ (Martín-Orúe et al., 2000).

Data were analyzed statistically as a Latin square design, with period and treatment as fixed effects and cow as the random effect. When the effect of period was not statistically significant $(P>0.1)$, it was not included in the model. The model used was

$$
\mathrm{Y}_{\mathrm{ijk}}=\mu+\mathrm{D}_{\mathrm{i}}+\mathrm{A}_{\mathrm{j}}+\mathrm{P}_{\mathrm{k}}+€_{\mathrm{ink}}
$$

where $D_{i}, A_{j}$, and $P_{k}$ are the effects of dietary treatment, animal, and period, respectively.

When estimates of the same parameter (chemical composition of microbes or duodenal flow of $\mathrm{PB}$ ) were compared, the data were analyzed using a split-plot design, as follows: the main-plot effects (diet [D], animal $[\mathrm{A}]$, and period $[\mathrm{P}])$ were compared with the first error term $\left(€_{1}\right.$; period $\times$ animal), and the sub-plot effects (estimation method $[\mathrm{M}]$ and its interactions) were compared with the residual error term $\left(€_{2}\right)$. The model applied is as follows:

$$
\begin{gathered}
\mathrm{Y}_{\mathrm{ijk}}=\mu+\mathrm{D}_{\mathrm{i}}+\mathrm{A}_{\mathrm{j}}+\mathrm{P}_{\mathrm{k}}+\mathrm{A} \\
\times \mathrm{Pj}_{\mathrm{k}}+\mathrm{M}_{\mathrm{t}}+\mathrm{MD}_{\mathrm{ti}}+\mathrm{MA}_{\mathrm{tj}}+\mathrm{MP}_{\mathrm{tk}}+€_{\mathrm{ijkt}} .
\end{gathered}
$$

Data were analyzed using the mixed model procedure (SAS, 2000). The level for statistical significance was set at $P<0.05$, and trends were suggested when $P<0.1$.

\section{RESULTS}

Following AFRC (1993), food supply at "ad libitum" level was determined according to the individual cow's requirement, assuming no loss of BW. Animals remained in good health throughout the experiment, and diets were readily accepted; waste always amounted to $<5 \%$ of the feed offered. Average live weight and milk production for the 3 feed levels are presented in Table 2 .

\section{Feed Intake and Digestibility}

Average intake of digestible OM (DOM) apparently digested in the whole tract or in the rumen together with apparent coefficients of DM, OM, and NDF in the rumen and in the whole tract are presented in Table

\begin{tabular}{|c|c|c|c|c|c|}
\hline & \multicolumn{3}{|c|}{ Ad libitum intake } & \multirow{2}{*}{$\begin{array}{l}\text { SEM } \\
(\mathrm{n}=4)\end{array}$} & \multirow[b]{2}{*}{$P$} \\
\hline & $100 \%$ & $85 \%$ & $75 \%$ & & \\
\hline Live weight (kg) & 565 & 549 & 562 & & \\
\hline Milk yield (kg/d) & 18.3 & 20.3 & 20.3 & 1.34 & NS \\
\hline Protein $(g / d)$ & 558.8 & 660.1 & 612.8 & 51.75 & NS \\
\hline \multicolumn{6}{|l|}{$\begin{array}{l}\text { Composition of the } \\
\mathrm{N} \text { fraction }\end{array}$} \\
\hline $\mathrm{N}$ fraction & & & & & \\
\hline Total N (g/L) & 4.99 & 5.2 & 4.87 & 1.20 & NS \\
\hline Purine N (mg/L) & 13.01 & 13.63 & 14.02 & 0.63 & NS \\
\hline
\end{tabular}

Table 2. The yield and components of milk produced by 3 dairy cows subjected to 100,85 , and $75 \%$ ad libitum diets in a Latin Square Experimental Design.

3. No significant changes in DM, OM, and NDF digestibility were detected in the whole tract or in the rumen, and, therefore, the change in intake of DOM and OM apparently digested in the rumen (OMADR) reflected the effects of feed restriction (Table 3).

\section{Rumen Parameters}

The highest and lowest rumen $\mathrm{pH}$ values were reached at $2(\mathrm{pH}=6.58)$ and $12 \mathrm{~h}(\mathrm{pH}=6.0)$ after the first daily feeding, respectively, independent of the level of feed intake (Table 4). Apparently, ammonia concentrations were higher in animals fed ad libitum, although differences among treatments were not statistically significant. Independent of feed level, the lowest ammonia values occurred 7 to $10 \mathrm{~h}$ after the first daily feeding. Neither average VFA concentra-

Table 3. Daily intake (kg/d) of DM, digestible OM (DOM) apparently digested in the whole tract or the rumen (OMADR) together with apparent digestibility coefficient (\%) of the DM, OM, and NDF in the whole tract and in the rumen in 3 dairy cows, each subjected to 100 , 85 , and $75 \%$ ad libitum diets in a Latin square experimental design.

\begin{tabular}{lrrrrr}
\hline & \multicolumn{3}{c}{ Ad libitum intake } & & \\
\cline { 2 - 4 } & $100 \%$ & $85 \%$ & $75 \%$ & $\operatorname{SEM}^{1}(\mathrm{n}=4)$ & $P$ \\
\hline Intake (kg/d) & & & & & \\
DM & 16.38 & 13.92 & 12.99 & - & - \\
DOM & 10.50 & 8.20 & 8.00 & 0.16 & $* *$ \\
OMADR & 7.50 & 5.90 & 5.98 & 0.25 & $*$ \\
Apparent digestibility & & & & & \\
Whole tract & & & & & \\
DM & 71.0 & 66.2 & 68.8 & 1.49 & NS \\
OM & 71.5 & 66.4 & 69.1 & 1.33 & NS \\
NDF & 55.4 & 47.7 & 51.8 & 4.68 & NS \\
Rumen & & & & & \\
DM & 50.1 & 48.6 & 49.8 & 2.66 & NS \\
OM & 51.3 & 47.5 & 51.7 & 2.48 & NS \\
NDF & 58.8 & 43.2 & 49.4 & 12.06 & NS \\
\hline
\end{tabular}

${ }^{1} \mathrm{SEM}=$ Standard error of animal $\times$ period as the error term to test $\operatorname{diet}(\mathrm{D})$, period $(\mathrm{P})$, and animal (A) effect.

$* P<0.05$.

$* * P<0.01$. 
Table 4. Effect of feed restriction on the $\mathrm{pH}$, ammonia concentrations, and VFA concentrations in the rumen fluid of 3 dairy cows subjected to 100,85 , and $75 \%$ ad libitum diets in a Latin square experimental design.

\begin{tabular}{lccccc}
\hline & \multicolumn{3}{c}{ Ad libitum intake } & & \\
\cline { 2 - 4 } & $100 \%$ & $85 \%$ & $75 \%$ & SEM (n = 4) & $P$ \\
\hline $\mathrm{pH}$ & 6.00 & 6.31 & 6.34 & 0.04 & $*$ \\
$\mathrm{NH}_{3} \mathrm{~N}(\mathrm{mg}$ of N/L) & 86.7 & 61.1 & 68.6 & 7.95 & $\mathrm{NS}$ \\
Total VFA (mmol/L) & 81.3 & 76.8 & 85.7 & 3.69 & $\mathrm{NS}$ \\
Molar proportion & & & & & \\
of VFA (mol/100 mol) & & & & & $\mathrm{NS}$ \\
$\quad$ Acetate (A) & 66.2 & 68.3 & 71.0 & 2.99 & $\mathrm{NS}$ \\
Propionate (P) & 22.7 & 19.8 & 18.7 & 0.65 & $\mathrm{NS}$ \\
Butyrate & 6.0 & 7.3 & 6.2 & 0.30 & $\dagger$ \\
A:P & 2.93 & 3.45 & 3.79 & 0.10 & \\
\hline$* P<0.05$. & & & & & \\
$\dagger P<0.1$. & & & & & \\
& & & & &
\end{tabular}

tions, nor the relative $M$ proportions differed among experimental treatments.

\section{Chemical Composition of Rumen Microbial Extracts}

Average OM content did not differ significantly between bacterial extracts $(89.2 \pm 1.5 \%$ and $91.7 \pm 1.6 \%$ for LAB and SAB isolates, respectively; Table 5), although LAP had a lower proportion of OM $(80.0 \pm 1.0 \%$; $P<0.001)$. The $\mathrm{N}$ and $\mathrm{PB}$ content of $\mathrm{SAB}$ and LAP isolates were similar $(8.57 \pm 0.47$ and $8.63 \pm 0.46 \mathrm{~g}$ of
$\mathrm{N} / 100 \mathrm{~g}$ of $\mathrm{OM}$ and $117 \pm 8.1$ and $117 \pm 14.2 \mu \mathrm{mol}$ of $\mathrm{PB} / \mathrm{g}$ of OM, respectively), and significantly $(P<0.001)$ lower than those of the extracts from the LAB (10.35 $\pm 1.09 \mathrm{~g}$ of $\mathrm{N} / 100 \mathrm{~g}$ of $\mathrm{OM} ; 218 \pm 17.9 \mu \mathrm{mol}$ of $\mathrm{PB} / \mathrm{g}$ of $\mathrm{OM})$. Differences in $\mathrm{PB}$ were greater than those in $\mathrm{N}$; consequently, the PB:N was significantly $(P<0.001)$ lower in protozoa and SAB $(1.36 \pm 0.23)$ than in LAB extracts $(2.09 \pm 0.42)$. No significant differences caused by feed restriction were observed, and average $P B: n$ values $(2.09 \pm 0.27$ for $\mathrm{LAB}$ and $1.36 \pm 0.10$ for $\mathrm{SAB})$ were used to estimate $\mathrm{MN}$ flow based on the duodenal flow of PB.

\section{CT Rate}

Although urine was collected using external separators fixed to the vulva, some urine was lost. Inulin was used to estimate urinary CT as an internal marker of renal excretion (Martín-Orúe et al., 2000a). Inulin was infused continuously ( $50 \mu \mathrm{g} / \mathrm{min}$ per $\mathrm{BW}^{0.75}$ ), and the equilibrium time of inulin in the plasma pool was taken to be when values reached a maximum, following the method of Martín-Orúe et al. (2000a), and validated in dairy cows (González-Ronquillo et al., 2003). Average values of CT from the urine of each of the 3 animals $(829 \pm 55,416 \pm 137$, and $729 \pm 120 \mu \mathrm{mol} / \mathrm{kg}$ of $\mathrm{BW}^{0.75}$ ) were significantly lower than the values obtained by inulin dilution $(111 \pm 13,114 \pm 10$, and

Table 5. Concentration of $\mathrm{OM}, \mathrm{N}$, purine bases (PB), and the PB:N of protozoa (LAP) and bacteria isolated from the liquid (LAB) or the solid phase (SAB) of rumen content in 3 lactating cows subjected to 100,85 , and $75 \%$ ad libitum diets in a Latin square experimental design.

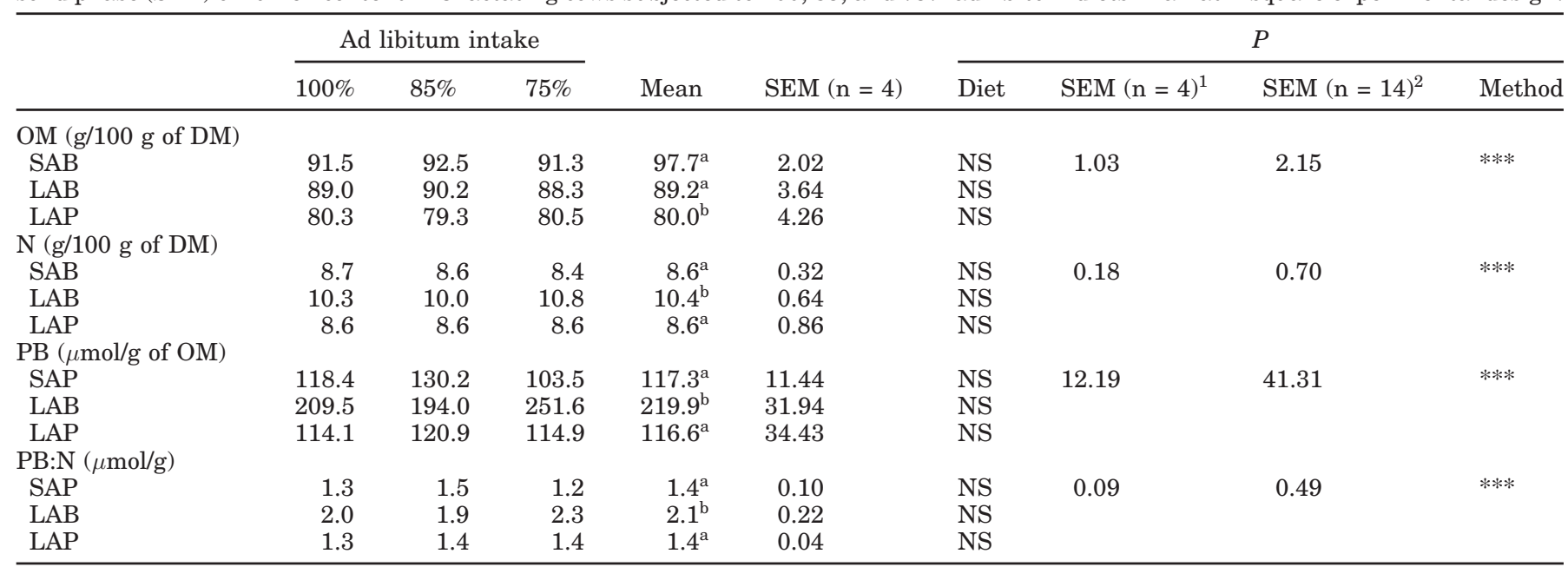

${ }^{\mathrm{a}, \mathrm{b}}$ Mean values within a column with unlike superscripts were significantly different.

${ }^{1} \mathrm{SEM}=$ Standard error of animal $\times$ period as the error term to test diet (D), period (P), and animal (A) effect in the split plot analysis The SEM is within each microbial sample.

${ }^{2} \mathrm{SEM}=$ Standard error of residual term of the split-plot analysis, used to test effect of methodology employed. The SEM is within each microbial sample.

$* * * P<0.001$. 
Table 6. Urine volume and daily excretion rates of purine derivatives (PD) through urine or milk and PD concentrations in milk from 3 lactating dairy cows each subjected to 100,85 , and $75 \%$ ad libitum diets in a Latin square experimental design.

\begin{tabular}{|c|c|c|c|c|c|}
\hline & \multicolumn{3}{|c|}{ Ad libitum intake } & \multirow[b]{2}{*}{ SEM $(\mathrm{n}=4)$} & \multirow[b]{2}{*}{$P$} \\
\hline & $100 \%$ & $85 \%$ & $75 \%$ & & \\
\hline Urine volume $(\mathrm{L})$ & 11.4 & 8.5 & 12.4 & 2.38 & NS \\
\hline \multicolumn{6}{|l|}{ Urinary excretion $(\mathrm{mmol} / \mathrm{d})$} \\
\hline Allantoin & 256.0 & 235.9 & 224.8 & 10.49 & NS \\
\hline Uric acid & 34.7 & 24.2 & 18.5 & 3.46 & $\dagger$ \\
\hline Total PD & 290.6 & 260.1 & 243.3 & 8.10 & * \\
\hline \multicolumn{6}{|l|}{ Milk excretion $(\mathrm{mmol} / \mathrm{d})$} \\
\hline Allantoin & 2.9 & 3.6 & 3.7 & 0.336 & NS \\
\hline Uric acid & 1.4 & 1.4 & 1.5 & 0.132 & NS \\
\hline Total PD & 4.3 & 5.0 & 5.2 & 0.341 & $\dagger$ \\
\hline \multicolumn{6}{|l|}{ Milk concenration $(\mu \mathrm{mol} / \mathrm{L})$} \\
\hline Allantoin & 159.4 & 178.3 & 181.1 & 19.17 & NS \\
\hline Uric acid & 74.8 & 69.5 & 72.8 & 4.44 & NS \\
\hline Total PD & 234.2 & 247.7 & 254.0 & 20.04 & NS \\
\hline
\end{tabular}

$* P<0.05$.

$\dagger P<0.1$.

$112 \pm 10 \mathrm{mmol} / \mathrm{d}$ or $924 \pm 117,1015 \pm 61$ and $982 \pm 71$ $\mu \mathrm{mol} / \mathrm{kg}$ of $\left.\mathrm{BW}^{0.75}\right)$.

\section{Milk Yield and Milk Components}

Apparently, milk yield was influenced negatively by DMI, although differences were not statistically significant (Table 2). Average $\mathrm{N}$ concentration in milk was $5.02 \pm 0.06 \mathrm{~g} / \mathrm{L}$, of which $17 \%(0.85 \mathrm{~g} / \mathrm{L})$ was urea $\mathrm{N}$, and purine $\mathrm{N}$ was a minor proportion $(0.26 \% ; 13.46$ $\mathrm{mg} / \mathrm{L}$ ) of total N. Milk yields and milk components did not vary significantly among treatments.

\section{Urinary and Mammary Excretion of Purine Compounds}

Allantoin was the predominant PD (approximately 90\%), and although its excretion apparently decreased with increased feed restriction, differences were not statistically significant (Table 6). Uric acid excretion rates tended $(P<0.1)$ to decrease with an increase in feed restriction. Xanthine or hypoxanthine was not detected in urine samples. Apparently, in response to the experimental treatment, daily $\mathrm{PD}$ excretion rates in urine decreased significantly $(P<0.05$; Table 6$)$.

Purine derivatives excreted through milk was a minor proportion $(1.8 \pm 0.15 \%)$ of the total PD excreted, and its profile differed from that in urine. Milk proportion of uric acid was $>30 \%$, which supports the role of the mammary gland in the excretion of uric acid. Milk concentrations and milk excretion rates were not significantly affected by the experimental treatment $(P$ $>0.05)$.

\section{Post-Rumen Nutrient Supply and Microbial Synthesis}

As an index of the duodenal flow of PB, urinary PD excretion produced higher values $(290.56 \mathrm{mmol} / \mathrm{d})$ than those estimated directly from the duodenum $(\mathrm{Cr} /$ $\mathrm{Yb}, 209.32 \mathrm{mmol} / \mathrm{d})$ or using milk PD $(238.21 \mathrm{mmol} / \mathrm{d}$; Table 7). Values of MN flow reflected duodenal flow of $\mathrm{PB}$, although values of rumen microbial synthesis were always related to the method used, bacterial (LAB/SAB) reference, and the estimation method.

Apparently, fractions of duodenal digesta decreased with increased feed restriction, although differences among values of $\mathrm{N}$ flow were not statistically significant. There was a trend for reduced duodenal $(\mathrm{Cr} / \mathrm{Yb})$ PB flow (from 258.2 to $154.6 \mathrm{mmol} / \mathrm{d} ; P<0.1$ ), and differences were statistically significant when duodenal flow of PB was determined from urinary PD excretion (from 314.0 to $266.5 \mathrm{mmol} / \mathrm{d} ; P<0.03$ ). Milk PD excretion was not affected by the experimental treatment.

Microbial contribution to the duodenal NAN flow in animals fed ad libitum was 59, 75, and $51 \%$ when estimated using duodenal $\mathrm{PB}$, urinary $\mathrm{PD}$, and milk $\mathrm{PD}$ excretion, respectively, using $\mathrm{LAB}$ as a microbial reference. High contributions $(P<0.05)$ were obtained using $\mathrm{SAB}$ as a reference in combination with duodenal PB $(86 \%)$, urinary PD $(113 \%)$, or mammary PD excretion (81\%), which reflected the lower PB:N determined in such adherent population (SAB).

The estimated efficiency of microbial synthesis ( $\mathrm{g}$ of N/kg OMADR) was 15.2 (LAB) and 23.86 (SAB) using duodenal $\mathrm{PB}(\mathrm{Cr} / \mathrm{Yb})$ as a microbial marker, and 22.02 $(\mathrm{LAB})$ and $33.83(\mathrm{SAB})$ using urinary excretion of $\mathrm{PD}$. 
Table 7. Nitrogen $(\mathrm{N})$ intake and duodenal flow of $\mathrm{N}$, NAN (g/d), purine bases (PB; mmol/d), and microbial N (g/d) calculated using the dual-marker $(\mathrm{Cr}-\mathrm{Yb})$ technique, with $\mathrm{PB}$ as the microbial marker in 3 lactating dairy cows each subjected to 100, 85, and $75 \%$ ad libitum diets in a Latin square experimental design. Duodenal flow of PB is also estimated indirectly based on the excretion of purine derivatives through urine or milk. In all cases, microbial $\mathrm{N}$ was calculated based on the ratio of $\mathrm{PB}$ to $\mathrm{N}$ (PB:N) and determined in the solid- (SAB) or liquid-associated bacteria (LAB).

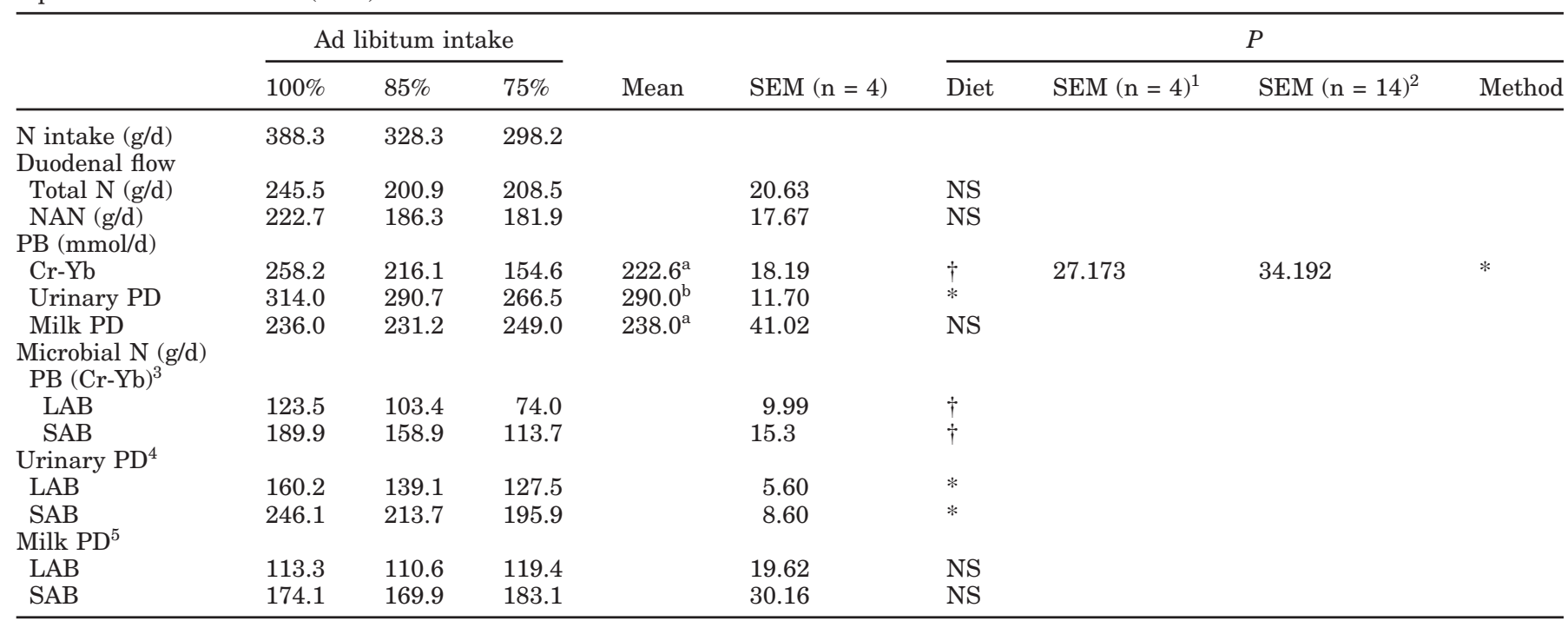

${ }^{\mathrm{a}, \mathrm{b}}$ Mean values within a column with unlike superscripts were significantly different.

${ }^{1} \mathrm{SEM}=$ Standard error (within each method) of animal $\times$ period as error term to test diet (D), period (P), and animal (A) effect in the split-plot analysis.

${ }^{2} \mathrm{SEM}=$ Standard error (within each method) of residual term of the split-plot analysis used to test effect of methodology employed.

${ }^{3}$ Values calculated using a double-marker system (Faichney, 1975).

${ }^{4}$ Values calculated using the predictive model proposed by González-Ronquillo et al. (2003) from the urinary purine derivatives ( $\mathrm{y}=58.86$ $+0.69 \mathrm{x}$, where $\mathrm{y}$ is the PD excreted in urine $(\mathrm{mmol} / \mathrm{d})$ and $\mathrm{x}$ is the duodenal flow of $\mathrm{PB}(\mathrm{mmol} / \mathrm{d})$ ).

${ }^{5}$ Values are calculated using the predictive model proposed by González-Ronquillo et al. (2003) from the milk PD excretion [y $=-5.14+$ $0.3765 \mathrm{x}_{1}+0.011 \mathrm{x}_{2}$, where $\mathrm{y}$ is the PD excreted in urine $(\mathrm{mmol} / \mathrm{d}), \mathrm{x}_{1}$ is the duodenal flow of PB $(\mathrm{mmol} / \mathrm{d})$, and $\mathrm{x}_{2}$ is milk yield $\left.(\mathrm{L})\right]$.

$* P<0.05$.

$P<0.1$.

Feed restrictions did not appear to influence the efficiency of microbial synthesis.

\section{DISCUSSION}

Mammary excretion of PD in dairy cows (Tiemeyer et al., 1984; González-Ronquillo et al., 2003) might limit the usefulness of urinary excretion as a predictive index of rumen microbial yield or, alternatively, may allow for monitoring the synthesis of microbial proteins in the rumen of lactating animals (Giesecke et al., 1994). In most of the studies on the usefulness of milk PD as an index of microbial protein synthesis, milk yield was positively correlated with urinary excretion of $\mathrm{PD}$ as an increase in rumen microbial synthesis usually implies an increase in energy and protein supply to the host animal and, consequently, an improvement in milk yield. Duodenal infusion of NA through a cannula, without altering energy and protein metabolism, avoids the bias caused by this relationship. In this study, the objective was to determine the relationship between duodenal $\mathrm{PB}$ flow and the excretion of PD through urine and milk in dairy cows under normal feeding conditions. However, to determine the microbial yield by simultaneously using conventional methods and an indirect method based on $\mathrm{PD}$ excretion requires cannulated milking cows. In our case, cows were in similar physiological and milk yield conditions, and a Latin square design was used to maximize the statistical rigor of the experiment.

\section{Intake, Digestibility, and Rumen Parameters}

Feed intake was reduced from 90.6 to $69.3 \mathrm{~g}$ of DOM/ $\mathrm{kg}$ of $\mathrm{BW}^{0.75}$ (or from 3.2 to 2.5 times maintenance requirements AFRC, 1993) without a significant effect on milk yield. An apparent total tract digestibility of $\mathrm{DM}$ value of $68.6 \pm 0.49$ was similar to those values reported for animals under similar experimental conditions (Susmel et al., 1995; Wright et al., 1998; Shingfield et al., 2002). In this study, rumen DM digestibility $(49.5 \pm 0.7)$ was within the range ( 47 to $52 \%)$ of values reported by others (Beever et al., 1972; Aldrich et al., 1993; Yang et al., 1997). 


\section{Inulin as a Urinary Marker}

When inulin is infused continuously through the jugular vein and equilibrated within the body pools, the infusion rate must be equal to the excretion rate before inulin can be used as a urinary marker (Martín-Orúe et al., 2000a). Creatinine has been shown to have properties similar to those of inulin and is commonly used to study renal metabolism in humans and other animals (Brody, 1945).

In our study, daily $\mathrm{CT}\left(\mu \mathrm{mol} / \mathrm{kg}\right.$ of $\left.\mathrm{BW}^{0.75}\right)$, when estimated by the inulin dilution method, were similar to those we reported previously (1015 and 921; González-Ronquillo et al., 2003) and those reported in growing heifers (896.8; Martín-Orúe et al., 2000a) and dairy cows (from 800 to 985; Susmel et al., 1994; Gonda et al., 1996; Vagnoni et al., 1997). Thus, values determined from inulin dilution in spot urine samples were consistent with previous studies but higher than the values based on total collected urine, which also show remarkable individual variation.

\section{Urinary Excretion of PD}

In this study, average PD excretion (264.6 \pm 8.10 $\mathrm{mmol} / \mathrm{d}$ ) by 3 dairy cows was within the range reported by others (Dewhurst et al., 1996; Gonda and Lindberg, 1997; Keady et al., 1998; Shingfield and Offer, 1998), and the PD profile in urine might be explained by the high levels of xanthine-oxidase activity (as the enzyme responsible for the oxidation of xanthine and hypoxanthine to uric acid) in intestinal mucosa and liver (Balcells et al., 1992a).

In our experiment, PD excretion (from 2108 to 2520 $\mu \mathrm{mol} / \mathrm{kg}$ of $\mathrm{BW}^{0.75}$ ) was higher than the endogenous losses reported in lactating (González-Ronquillo et al., 2003) or dry (309 $\mu \mathrm{mol} / \mathrm{kg}$ of $\mathrm{BW}^{0.75}$; Orellana-Boero et al., 2001) cows and in growing steers $(363 \mu \mathrm{mol} / \mathrm{kg}$ $\mathrm{BW}^{0.75}$, Verbic et al., 1990). Differences in PD excretion must be a result of variation in the duodenal flow of exogenous $\mathrm{PB}$, especially in cattle, where endogenous and exogenous purines constitute 2 independent compartments (Balcells et al., 1992a). Our results (Table 6) confirm that the PD technique can accurately predict changes in duodenal PB flow. Feed restriction and the decrease in OMADR (approximately 20\%; Table 3) were reflected by the amount of PD excreted in urine. Total PD excretion decreased by $17 \%$, but when the endogenous contribution ( $58.86 \pm 3.89 \mathrm{mmol} / \mathrm{d}$; González-Ronquillo et al., 2003) was taken into account, the decrease in urinary PD from exogenous origins closely reflects the differences produced by the experimental treatment $(22.81 \%)$.

\section{Mammary Excretion of PD}

A high level of xanthine-oxidase activity (Ortín et al., 1991) and the absence of uricase (Giesecke et al., 1994) explain the high proportion of uric acid and the undetectable concentrations of xanthine and hypoxanthine in dairy milk. Similar PD profiles have been reported in cows (Giesecke et al., 1994; Vagnoni et al., 1997; González-Ronquillo et al., 2003) and ewes (Martín-Orúe et al., 1996) and suggest than only allantoin excretion through the milk should be used as a predictive index of duodenal $\mathrm{PB}$ flow, given that it seems that uric acid is also synthesized at the mammary gland (Martín-Orúe et al., 1996).

Allantoin secreted in milk is derived from plasma as a result of passive diffusion through the alveolar cells (Giesecke et al., 1994). As such, the production of milk allantoin depends on the concentration of $\mathrm{PD}$ in plasma and mammary blood flow (Martín-Orúe et al., 1996). Our results are consistent with that hypothesis, given the weak relationship between duodenal input and mammary output of purine compounds. González-Ronquillo et al. (2003) evaluated the effect of milk yield and duodenal flow of PB on PD excretion in milk and found that milk yield explained about $70 \%$ of the variation in milk PD. The inclusion of duodenal $\mathrm{PB}$ as a second variable (in a stepwise regression model) reduced unexplained variation only by $15 \%$. The low concentration of PD in milk samples, analytical difficulties, and the correlation between milk yield and PD (or allantoin) excretion by the mammary gland raises questions about the use of milk allantoin as an index of the microbial protein supply in dairy cow.

\section{Microbial Protein Production: Evaluation of the 2 Predictive Indices}

Microbial composition. In agreement with most researchers (Ben-Ghedalia et al., 1978; Chanberlain and Thomas, 1979; Storm and Ørskov, 1983; Martin et al., 1994), microbial composition was unaffected by dietary treatments. However, there were relevant differences among microbial extracts.

Changes in PB:N may be associated with different bacterial species (Obispo and Dehority, 1999) or growth rate (Legay-Carmier and Bauchart, 1989). However, existing information suggests that the isolation process may have a significant implication, considering the low detachment efficiency of adherent bacteria (0.6; Martín-Orúe et al., 1998) and their incomplete recovery (0.32 to 0.50; Martín-Orúe et al., 1998; Ranilla and Carro, 2003). In general, LAB extracts render a high PB:N, and a higher estimation of microbial protein synthesis than $\mathrm{SAB}$ when $\mathrm{PB}$ are used as microbial markers. It is difficult to establish the real 
synthesis and contribution to total microbial synthesis in the rumen for SAB because of both its uncertain composition and the fact that its impact depends on the type of diet (Faichney, 1980; Volden, 1999). In any case, microbes can be associated with several rumen phases, and the dual (LAB/SAB) phase system is always an oversimplification of the real situation.

Indeed, the lack of representativeness of the microbial sample is one of the most critical points for the determination of rumen microbial synthesis. Presented results from this work assume that all microbes are vehiculated either through the solid or the liquid phase and then values reflect a potential range where the true value might be allocated, although in some cases estimation may result in unrealistic values.

MN synthesis. Duodenal measurements. Estimates of microbial yields derived from our proposed model (González-Ronquillo et al., 2003) based on the fact that urinary PD excretion consistently overestimated the values obtained from direct flows measurements $(\mathrm{Cr} / \mathrm{Yb})$. In both cases, the same approach was used to calculate microbial yield, thus differences between methods might be explained by differences in the urinary recovery of duodenal purines compared with the ratio established in the response model or an underestimation of PB flow derived from the dualmarker method.

In our study, differences in the recovery ratio were minimized (duodenal:urinary purine compounds) by using the same animals and diets in similar physiological condition. Nevertheless, some specific characteristics used in the model can hinder the detection of the true recovery ratio, i.e., the use of RNA yeast instead of digestive PB. It is necessary, however, to appreciate that a high yeast RNA digestibility in relation to digestive $\mathrm{PB}$ will lead to the opposite result, a underestimation of PD-derived values, which was observed in ewes (Pérez et al., 1996b).

Flow studies based on the dual marker technique are considered standard to verify indirect methods (Pérez et al., 1996a). However, they are not error free. Therefore, an underestimation of the dual-marker flow system cannot be discarded.

The level of feed restriction affected duodenal flow of $\mathrm{PB}$, regardless of the method of estimation. The decrease in duodenal PB flow tends to be significant when estimated directly, whereas changes in urinary PD were statistically significant. The high sensitivity of urinary PD is, in part, a result of the residual variation in estimated urinary $\mathrm{PD}$ values $(\mathrm{CV}=6.9)$ being about one-half of the residual variation of duodenal $\mathrm{PB}(\mathrm{Cr}-\mathrm{Yb})$ measurements $(\mathrm{CV}=15.7)$ using the dualmarker system. Our data confirm the validity of the PD method as an alternative to conventional methods and is able to detect changes in rumen microbial synthesis of the magnitude induced by the experimental reduction in feed intake used in our study.

\section{Mammary Gland Excretion of PD as an Index of Microbial Protein Synthesis}

Estimates of duodenal $\mathrm{PB}$ or MN from milk had high residual variation ( $C V=29.8$ for $\mathrm{PB}$ estimated values). Furthermore, this method does not detect changes induced by the experimental treatment and seems to be more sensitive to changes in milk production, which is consistent with other findings in milking ewes (Martín-Orúe et al., 1996) and dairy cattle (Shingfield and Offer, 1998). Milk excretion of PD is not a suitable substitute for urinary PD excretion as an index of microbial protein synthesis.

\section{CONCLUSIONS}

Our study demonstrated the usefulness of urinary $\mathrm{PD}$ as a means of detecting changes in rumen microbial synthesis, with at least the same efficacy as duodenal measurements based on the dual flow marker technique. Purine derivative excretion in milk did not reflect changes in duodenal PB.

\section{ACKNOWLEDGMENTS}

This study was supported by the CICYT Project 950498. M. González-Ronquillo was supported by the Instituto de Cooperacion Iberoamericana (Spain) and Universidad Autónoma del Estado de Mexico (Mexico). For isotope analyses, thanks are extended to R. Redondo, Faculty of Sciences, U.A.M.

\section{REFERENCES}

Aldrich, J. M., L. D. Muller, and G. A. Varga. 1993. Non-structural carbohydrate and protein effects on rumen fermentation, nutrient flow and performance of dairy cows. J. Dairy Sci. 76:1091-1105.

AFRC. 1993. Energy and Protein Requirements of Ruminants. CAB International, Wallingford, UK.

ARC. 1984. The Nutrient Requirement of Ruminant Livestock, Suppl. 1. CAB Commonwealth Agricultural Bureaux, England.

Association of Official Analytical Chemists. 1980. Official Methods of Analysis. 13th ed. AOAC, Washington, DC.

Balcells, J., J. A. Guada, C. Castrillo, and J. Gasa. 1991. Urinary excretion of allantoin and allantoin precursors by sheep after different rates of purine infusion into the duodenum. J. Agric. Sci. (Camb.). 116:309-317.

Balcells, J., J. A. Guada, J. M. Peiró, and D. S. Parker. 1992b. Simultaneous determination of allantoin and oxypurines in biological fluids by high-performance liquid chromatography. J. Chromatogr. 575:153-157.

Balcells, J., D. S. Parker, and C. J. Seal. 1992a. Purine metabolite concentrations in portal and peripheral blood of steers, sheep and rats. Comp. Biochem. Physiol. 101B:633-636.

Beever, D. E., J. F. Coelho da Silva, J. H. D. Prescott, and D. G. Armstrong. 1972. The effect in sheep of the physical form and 
stage of growth on the sites of digestion of dried grass. 1. Sites of absorption of organic matter, energy and carbohydrates. Br. J. Nutr. 28:347-356

Belenguer, A., D. Yañez, J. Balcells, N. H. Ozdemir Baber, and M. González-Ronquillo. 2002. Urinary excretion of purine derivatives and prediction of rumen microbial outflow in goats. Livest. Prod. Sci. 77:127-135.

Ben-Ghedalia, D. J., N. P. McMeniman, and D. G. Armstrong. 1978. The effect of partially replacing urea nitrogen with protein $\mathrm{N}$ on $\mathrm{N}$ capture in the rumen of sheep fed a purified diet. Br. J. Nutr. 39:37-44.

Brody, S. 1945. Bioenergetics and Growth. Reinhold Publishing Corporation, New York, NY.

Chanberlain, D. G., and P. C. Thomas. 1979. Ruminal nitrogen metabolism and the passage of amino acids to the duodenum in sheep receiving diets containing hay and concentrates in various proportions. J. Sci. Food Agric. 30:677-686.

Chaney, A. L., and E. P. Marbach. 1962. Modified reagents for determination of urea and ammonia. Clin. Chem. 8:130-132.

Chen, X. B., F. D. DeB. Hovell, E. R. Ørskov, and D. S. Brown. 1990. Excretion of purine derivatives by ruminants: Effect of exogenous nucleic acid supply on purine derivative excretion by sheep. Br. J. Nutr. 63:131-142.

Coleman, G. S. 1978. Rumen entodiniomorphid protozoa. Pages 39 54 in Methods of Cultivating Parasites In Vitro. E. R. Taylor and J. R. Barker, ed. Academic Press, New York, NY.

Dewhurst, R. J., A. M. Mitton, N. M. Offer, and C. Thomas. 1996. Effects of the composition of grass silages on milk production and nitrogen utilization by dairy cows. Anim. Sci. 62:25-34.

Faichney, G. J. 1975. The use of markers to partition digestion within the gastrointestinal tract of ruminants. Pages 277-291 in Digestion and Metabolism in Ruminant. I. W. McDonald and A. C. I. Warner, ed. University of New England Publishing Unit, Armidale, Australia.

Faichney, G. J. 1980. Measurement in sheep of the quantity and composition of rumen digesta and of the fractional outflow rates of digesta constituents. Austr. J. Agric. Res. 31:1129-1137.

Firkins, J. L., W. P. Weiss, and E. J. Piwonka. 1992. Quantification of intraruminal recycling of microbial nitrogen using Nitrogen15. J. Anim. Sci. 70:3223-3233.

Giesecke, D. J., L. Ehrentreich, and M. Staingassinger. 1994. Mammary and renal excretion of purine metabolites in relation energy intake and milk yield in dairy cows. J. Dairy Sci. 77:2376-2381.

Goering, H. K., and P. J. Van Soest. 1970. Forage fiber analysis. Agricultural Research Service. Agricultural Handbook No. 379. US Department of Agriculture, Washington, DC.

Gonda, H. L., M. Emanuelson, and M. Murphy. 1996. The effect of roughage to concentrate ratio in the diet on nitrogen and purine metabolism in dairy cows. Anim. Feed Sci. Technol. 64:27-42.

Gonda, H. L., and J. E. Lindberg. 1997. Effect of diet on milk allantoin and its relationship with urinary allantoin in dairy cows. J. Dairy Sci. 80:364-373.

González-Ronquillo, M., J. Balcells, J. A. Guada, and F. Vicente. 2003. Purine derivatives excretion in dairy cows: Endogenous excretion and the effect of exogenous nucleic acid supply. J. Dairy Sci. $86: 1282-1291$.

Jouany, J. P. 1982. Volatile fatty acid and alcohol determination in digestive contents, silage juices, bacterial cultures and anaerobic fermenter contents. Sci. Aliment. 2:131-144.

Jung, K., S. Klozet, and B. Schulze. 1990. Refinements of assay for low concentrations of inulin in serum. Nephron 54:360-361.

Keady, T. W., C. S. Mayne, and M. Marsden. 1998. The effects of concentrate source on silage intake and animal performance with lactating dairy cows offered a range of grass silages. Anim. Sci. 66:21-33.

Legay-Carmier, F., and D. Bauchart. 1989. Distribution of bacteria in the rumen contents of dairy cows given a diet supplemented with soya-bean oil. Br. J. Nutr. 61:725-740.

Martin, C., A. G. Williams, and B. Michalet-Doreau. 1994. Isolation and characteristics of the protozoal and bacterial fractions from bovine ruminal contents. J. Anim. Sci. 72:2962-2968.
Martín-Orúe, S. M., J. Balcells, J. A. Guada, and M. Fondevila. 2000a. Microbial nitrogen production in growing heifers: direct measurement of duodenal flow of purine bases versus urinary excretion of purine derivatives as estimation procedures. Anim. Feed Sci. Technol. 88:171-188.

Martín-Orúe, S. M., J. Balcells, F. Vicente, and C. Castrillo. 2000b. Influence of dietary rumen-degradable protein supply on rumen characteristics and carbohydrate fermentation in beef cattle offered high-grain diets. Anim. Feed Sci. Technol. 88:59-77.

Martín-Orúe, S. M., J. Balcells, F. Zakraoui, and C. Castrillo. 1998. Quantification and chemical composition of mixed bacteria harvested from solid fractions of rumen digesta: Effect of detachment procedure. Anim. Feed Sci. Technol. 71:269-282.

Martín-Orúe, S. M., C. Dapoza, J. Balcells, and C. Castrillo. 1996. Purine derivatives excretion in lactating ewes fed straw diets with different levels of fishmeal. Anim. Feed Sci. Technol. 63:341-346.

National Research Council. 2001. Pages 55-58 in Nutrient Requirements of Dairy Cattle, 7th rev. ed. Natl. Acad. Press, Washington, DC.

Obispo, N. E., and B. A. Dehority. 1999. Feasibility of using total purines as a marker for ruminal bacteria. J. Anim. Sci. 77:3084-3095.

Orellana-Boero, P., J. Balcells, S. M. Martín-Orúe, J. B. Liang, and J. A. Guada. 2001. Excretion of purine derivatives in cows: Endogenous contribution and recovery of exogenous purine bases. Livest. Prod. Sci. 68:243-250.

Ortín, A., M. J. López-Pérez, M. T. Muiño Blanco, and J. A. Cebrián Pérez. 1991. Extraction of xanthine oxidase from milk by countercurrent distribution in an aqueous two-phase system. J. Chromatogr. 558:357-367.

Pérez, J. F., J. Balcells, J. A. Guada, and C. Castrillo. 1996a. Determination of rumen microbial nitrogen production in sheep: A comparison of urinary purine excretion with methods using $15 \mathrm{~N}$ and purine bases as markers of microbial-nitrogen entering the duodenum. Br. J. Nutr. 75:699-709.

Pérez, J. F., J. Balcells, J. A. Guada, and C. Castrillo. 1996b. Rumen microbial production estimated either from urinary purine derivative excretion or from direct measurements of $15 \mathrm{~N}$ and purine bases as microbial markers: Effect of protein source and rumen bacteria isolates. Anim. Sci. 65:225-237.

Pimpa, O., J. B. Liang, J. Balcells, Z. A. Jelan, and N. Abdullah. 2003. Absorption of nucleic acid in the small intestines of swamp buffaloes and Kedah-kelantan cattle. Anim. Feed Sci. Technol. 104:191-199.

Ranilla, M. J., and M. D. Carro. 2003. Diet and procedures used to detach particle-associated microbes from ruminal digesta influence chemical composition of microbes and estimation of microbial growth in Rusitec fermenters. J. Anim. Sci. 81:535-544.

SAS User's Guide: Statistics, Version 8 Edition. 2000. SAS Inst., Inc., Cary, NC.

Shingfield, K., S. Jaakkola, and P. Huhtanen. 2002. Effect of forage conservation method, concentrate level and propylene glycol on diet digestibility, rumen fermentation, blood metabolite concentrations and nutrient utilisation of dairy cows. Anim. Feed Sci. Technol. 97:1-21.

Shingfield, K. J., and N. W. Offer. 1998. Evaluation of the spot urine sampling technique to assess urinary purine derivative excretion in lactating dairy cows. Anim. Sci. 66:557-568.

Siddons, R. C., J. Paradine, D. E. Beever, and P. R. Cornell. 1985. Ytterbium acetate as a particulate phase digesta flow marker. Br. J. Nutr. 54:509-519.

Storm, E., and E. R. Ørskov. 1983. The nutritive value of rumen microorganisms in ruminant. 1. Large scale isolation and chemical composition of rumen microorganism. Br. J. Nutr. 50:463-470.

Susmel, P., M. Sphangero, B. Stefanon, and C. R. Mills. 1995. Nitrogen balance and partitioning of some nitrogen catabolites in milk and urine of lactating cows. Livest. Prod. Sci. 44:207-219.

Susmel, P., M. Sphangero, B. Stefanon, C. R. Mills, and E. Plazzotta. 1994. Digestibility and allantoin excretion in cow fed diets differing in nitrogen content. Livest. Prod. Sci. 39:97-99.

Tiemeyer, W., M. Stohrer, and D. Giesecke. 1984. Metabolites of nucleic acids in bovine milk. J. Dairy Sci. 67:723-728. 
Vagnoni, D. B., G. A. Broderick, M. K. Clayton, and R. D. Hatfield. 1997. Excretion of purine derivatives by Holstein cows abomasally infused with incremental amounts of purines. J. Dairy Sci. 80:1695-1702.

Verbic, J., X. B. Chen, N. A. McLeod, and E. R. Ørskov. 1990. Excretion of purine derivatives by ruminants. Effect of microbial nucleic acid infusion on purine derivative excretion by steers. J. Agric. Sci. (Camb.) 114:243-248.

Volden, H. 1999. Effects of level of feeding and ruminally undegraded protein on ruminal bacterial protein synthesis, escape of dietary protein, intestinal amino acid profile, and performance of dairy cows. J. Anim. Sci. 77:1905-1918.

Wright, T. C., S. Moscardini, P. H. Luimes, P. Susmel, and B. W. McBride. 1998. Effects of rumen-undegradable protein and feed intake on nitrogen balance and milk protein production in dairy cows. J. Dairy Sci. 81:784-793.

Yang, W. Z., K. A. Beauchemin, K. M. Koening, and L. M. Rode. 1997. Comparision of hull-less barley, barley, or corn for lactating cows: Effects on extent of digestion and milk production. J. Dairy Sci. $80: 2475-2486$. 